\title{
Subject and Network: Potential and Political Limits of the (Un)making of Bodies online*
}

\author{
Remedios Zafra**
}

\begin{abstract}
This essay concerns subjective construction on the Internet, the potential and limitations for the deconstruction of the social meanings of the body (there where, interfaced and displaced by the machine, it is made, but factitiously). Potentials and limits also for the ideation of camouflaged forms of repetition and symbolic repression present new technological scenarios. In this text, screens, as the material node of cyberspace, dress us and carry a new complexity in the identity and subjective constitution, to which are added the different spaces of the online relationship (such as social networks) which territorialize the Internet today; spaces that we think condition the presentation and representation of the "I" in its relationship with others and the constitution of desire and possible collectivities. The starting point will be the body as a symbolic construction, with its ways of seeing, its identity and social filters and its subjective pretensions; but also the subject from a materialist position that emphasizes the technologically located and amplified body, conditioned by the biopolitical design of the most common electronic devices of recent decades. From them we analyze some of the points of tension, possibilities and political conditionalities for subjective awareness and practice on the Internet.
\end{abstract}

Key Words: Subject, Internet, Bodies, Symbolic Construction, Gender.

\footnotetext{
* Received January 27, 2015, approved March 24, 2015.

Translated by Jeffrey Hoff. Reviewed by Richard Miskolci.

** Universidad de Sevilla. rzafra@us.es, www.remedioszafra.net.
} 
The only enemy is two. Monism and pluralism are the same thing because, in a certain way, it appears to me that any opposition, even all the possibilities for opposition between the single and the multiple, ... are the source of dualism, it is precisely the opposition between something that can be affirmed as one, and something that can be affirmed as multiple, and more precisely, that which indicates it as one is the subject of the enunciation, and that which indicates it as multiple is always the subject of the ennunciated.

GILLES DELEUZE

With relief, with humiliation, with terror, he understood that he was also an apparition, that another was dreaming of.

J. L. BORGES

Bodies are not completely ours. As much as you care for them, feed, them place make-up on them, improve them, caress them, kiss them, bare them and all the rest, bodies are ours but not completely ours. And that's where the story becomes political.

According to a suggestive description of the human body by Judith Butler we are "delivered to the other from the start" (Butler, 2006:43), in a way that even precedes individuation we are predefined by the other, and the result is the "social vulnerability of our bodies". This predefinition is a way to symbolically determine what society expects of us in relation to a body: an organism, an image, a sex, an age, a gender, a discourse,..."The face speaks. The manifestation of the face is already a discourse" (Lévinas, 1977:89). The process, however, implies a castration of the being as well as a social physical support. For Lévinas it is not advanced notice of the other but the encounter with the other which simultaneously installs a responsibility of the other in oneself (a construction in the other), so that the subject is responsible for the other even before being aware of its own existence (Lévinas, 1977).

But don't believe that all is made easier by supposing that our body is not completely ours, that it means "what it means" 
because of its relationship with others in a given sociocultural context, and do not believe that all personal commitment is annulled. To respect this argument does not imply a surrender, an abandonment of the will to the community flow, a transfer of our responsibility in the subjective formation, in its collective value. To be aware of the value of the "other" in the identity and subjective processes would be the first step in problematizing the body and proclaiming ourselves agents of its transformation; it supposes questioning what we are, not as something given, but as something individually and socioculturally modified, and as such, susceptible of being altered, not only materially and biotechnologically, but in terms of meaning and social value.

This constructivist thesis implies that the processes of production of bodies can be - up to a certain point - unveiled, understood and appropriated for political action. What is not clear is the effectiveness in the way of collectively making visible, resignifying or, even, "designifying" the body? To what degree is it possible for others, for the body itself as the body itself also constituted by others; to what degree can we convert this problem which is so common in artistic, feminist and queer practices into social politics that transcend people's lives?

Thus, the starting point is our body, as "symbolic construction" ${ }^{1}$, with its ways of seeing, its identity and social filters

${ }^{1}$ In his work Cuerpo y Espacio: Símbolos, Metáforas, Representación y Expresividad de las culturas (2007), Honorio Velasco evaluates this symbolic construction from the concept Embodiment, a term that is difficult to translate to Spanish, at times it is equivalent to "in-corporación" at others to "en-carnación". About it he indicates: "Since Foucault it was converted into an ineludible demand. In reality social theory had detected a gap that finally wound up being filled in. The body had erupted as a new paradigm, the embodiment." (Velasco, 2007:52). Embodiment alludes to the symbolic construction of the human body penetrated by social consturctions. The concept is an inheritance of the so-called Culture and Personality school for whose ideologs the relationship (motivations and intentions) between culture and person is incarnated in the body. It is a perspective that understands discourse from a cultural experience of "being in the world" and understand this this as a modality of becoming body, locating corporal experience as a support for culture and subjectivity. See: Csordas, 1994. 
and its subjective pretensions. I will make a parenthesis and observe my body. I want to identify a thousand patinas and filters of vision and in this way locate my discourse there. Give me a moment.

Space purposefully left blank

It's not easy and I nearly give up. So many normalized burdens. Although I am consoled to think that no more than all of you have. So, almost better with your company, I will question myself about them. Observe yours - your bodies: your faces, hair, belly, genitals, body hair, legs, perforations, fluids, corporal adornments, dresses and why not? Your screens - don't they make an interface and liminally join our bodies in online relations? Don't they operate as "necessary" appendixes of our habitation in a connected world?

Observe your culture in the bodies. The clothes and interfaces that are also body and that allow the human being to constitute itself in that it has chosen to be, "even [as Barthes recalled, paraphrasing Sartre] when that which it has chosen to be represents that which others have chosen in its place" (Barthes, 2003:418). And, now, and increasingly, screens as a material node of cyberspace, linked to the body; screens that not only dress us, but which introduce a new complexity by allowing the production of identities separated from the body, displaced, and usually hidden in our online interpersonal relations.

These possibilities of making the body invisible on the Internet or to transform it by taking advantage of the distinct uses that the digital screen, which like a gas mask (that disguises) or like 
a diving mask (that reveals), provides, presenting an additional value, converting the digital scenario into a territory for necessary reflection today about the body and the subject on the Internet, about the post-body or the non-body, if you prefer - the context is the same - and about the repercussions that this scenario has for subjectivity and for identity, as we will consider below.

But the intention here is not to provide keys to a possible resignification of the body through computer screens and cyberspace, nor to provide guidance about its use for making the body visible and the political demands derived from the body. The purpose is to question the circumstances in which operate the person-screen tandem and its possibilities, which are both deconstructive yet allow for the survival of heteropatriarchal and conservative models. Which the Internet allows and can do.

First, we see, it should be considered that in the virtual world the plurality of images of the "I" allow playing with and discovering aspects unknown to us. The experiment with the arbitrariness of the production of the "I" and of the "we" warns of a "correspondence between form and content," ${ }^{2}$ between the social body and the form of perceiving the physical body. Thus, all the imagination of this kind in the virtual world will inevitably involve the body. The fact that the Internet operates as a territory for liberation and corporal rest is something that we can observe and practice in cyberspace. Nevertheless, that in addition to this it does so as a territory whose circumstances favor a greater deconstructive potential (and thus the body is converted into representation and therefore into something factitious), is something that during the first years of the Internet many of us

2 In this regard Honorio Velasco (2007:56) indicates: "The theoretical antecedents go back to Mauss (who then analyzes it in detail) Freud and the concept of "conversion" of an emotional state into a physical state (...) and to Lévi-Strauss and the isomorphy of the symbolic structures. But even more to the classical rhetorical theory that preconceives a correspondence in the style between the forms and the contents or if you like between the literary style and the corporal style (...)". 
indicated and that, nevertheless, today has many possible specifications.

We begin with the material, through a "once upon a time there was a body alone in front of a computer connected to the Internet." Lets say that this body is yours and that you look at your screen. Before relating with this unknown person, you ask in silence: ¿Who are you? You can't get around this question. In this question you have to confront not only what you will formulate for the other, but also for yourself. The common response for the other won't take long, and will probably be that which before knowing, requires reinforcing what one knows. In fact, the response to this doubt, commonly establishes the prejudice in the repetition of the common. "To be" that which pacifies; that which culminates the performative act of being as is socially expected, to be "as always or as before," pre- censoring the different, the infrequent.

If all truly assumed existence implies reflecting upon oneself, taking a position in the construction of what we are, we cannot forget that this freedom implies an effort, a disturbance of the tranquility of the social identitary, which incites succumbing before the traditional identification; to be that which before discovering ourselves already identifies and socially locates us, in a tranquilizing, or better said, conservative manner.

Nevertheless, before the screen the body can be blinded and the response to ourselves can shift this affirmation to a questioning, some ellipses, as if reinforcing what we know was not enough, as if, however, it would be possible to not fool ourselves. A series of possibilities and divergences thus arises. I remove the mask... (in front of the screen I can be more of myself). I am what I am... I am many... (multitude-I). I am I, the enormous I. I invent myself... (pretend to be). "Lady... you are a man" (an echo from Orlando). And a thousand suspended points for each one...

It is clear that in all cases the fact that the response can be "common" provides us the key to understanding that it is not determined, that it is contingent and does not come written in the bodies, that it is recodifiable and potentially diverse. Although it is 
true that while the answer can be changed does not guarantee that it does change, or how it changes. Even knowing the circumstances in which the question is asked (who are you?) can give us more keys to understanding the replies.

One of the conditions that mark the common situation of the connected subject - its circumstances - is that established by the individualization of the interface of the computer equipment, that which marks the solitude of the access. I refer to the ideation of a machine, or the device thought of for "some eyes" for "some person" alone that looks, types or speaks. These circumstances of access are not neutral in respect to the possible identity response. The concentration before the machine (and those who it links us to) returns us to ourselves, faces us with the desire to be and with the failures of not having been, of not being. But the screen also locates us in the particular relaxation of an always prophylactic contact far from material dangers, from responsibility for what was said, from contamination, illnesses, procreation, commitments, from the reproduction of daily life and its collective norms even though more than ever guided by desire.

It is the solitude that determines the intimate alliance between the machine and the subject or between the subjects through the machine. Millions of connected people, yes, but millions of people alone looking at their screens, even when they share a single space. Inevitably, this image always brings to my mind that anecdote of Walter Benjamin about one of his first radio interventions. I believe it can be opportune in our reflection about this online conjuncture. Before participating in the program in question, Benjamin was given two warnings; one about the control of time and the other referring to the type of audience that may be listening:

Beginners (...) make the mistake of believing that they must give a talk before a pretty large public although circumstantially invisible. They couldn't be more wrong. The radio listener is nearly always alone, and even though a 
few thousand are listening, it will always be a few thousand individuals (...) (of) people alone (Benjamin, 1997:37).

Like the radio listeners, those connected are usually people alone in front of their device or computer, where each screen is just for one person - although interconnected they constitute a multitude. To the contrary, other screens like the television for example, can be seen in group, and in any case, maintain a spectator debilitated in the exercise of a more relaxed contemplation. As a suburbanizing medium, that with its repetitive and tranquilizing patterns, it consolidates the sense of security of the members of the community to which it is directed, placing us there where what we listen to and watch locates us. In fact, there are people that when they hear the news on television feel passive, that in this interval their home is not totally theirs (the clarity of the discourse, the intensity of the affirmations, the handling of the information, the hierarchy of what is important...).

In the solitude of the Internet connection this varies. The online drift does not usually create an option to appropriate our home so easily. We are outside the screen but we are also in it. In the solitude of the connection you can let yourself be led by the mythology of the "return home," to the place where we feel protected from the world, but "in" the world where the subject with his apparently passive body is active, where something of ours moves, although it is a mere blinking cursor on the line of search engine or an arrow that places us on the screen, and with it in the connected world.

But lets return to the body, the body connected to the liminal identity that is generated on the screen in these biopolitical conditions that we indicated (machines, conceived for hands that type and eyes that see, that is to say "personal" devices"). As such, the limit has a defining function that situates and at the same time protects something valuable, vulnerable, differentiated from the other but linked in itself. Its particularity would be that it mediates a shift, a want to be online implicated as agents in an individual condition. In such a way that if in a physical movement, the body 
is an active subject, in this case it appears that it is all that which is not body is that which acts and experiences the movement. In this virtual drift there is something liminal, of the limnality that Turner indicated in relation to the pilgrimages and the rites of passage (Turner and Turner, 1980:333), referring to this state still undefined by that which happens when you are no longer who you were, but still not someone new.

La liminalidad no es sólo transición sino también potencialidad, no sólo "llegar a ser", sino también "lo que puede ser", un ámbito de expresividad en el que todo lo que no es manifiesto en las operaciones diarias de la normalidad de la estructura social -ya sea a causa de represión social o porque se ha hecho cognitivamente invisible mediante una negación paradigmática prestigiosapuede ser objetivamente estudiado a pesar del carácter a menudo metafórico y elusivo de sus contenidos (Turner y Turner, 1978:3).

It is true that in this state of pre-identity that which you come to be on the Internet can already be limited beforehand by that which "you can come to be." The possibility to temporarily prescind the body and its vulnerability sketches a new scenario of identity experimentation that is undoubtedly valuable in the political subjectivity. To visualize this idea we can get help from the metaphor used by Victor and Edith Turner to refer to "pilgrimage" alluding to a route represented, no longer by a line between an origin and a destiny but by the figure of an ellipse, which reveals (although not made visible) a route of return, alluding to "returning" to the initial place "being already different."

We can define this process as a certain reversibility with consequences, that recall some puzzles where movement is always possible as long as we have a free space, the "empty space" 3 that

3 About this issue should be recalled the words of Žizêk (2006:232), "(The) same process of transiting between multiple identifications presumes a type of empty space (or open band) that allows the leap from one identity to another, and this open band is the subject itself." 
allows us to change position (Žizêk, 2006:232) (there will always be an unoccupied space but it does not have to coincide), precisely with what we can connect with subjectivity.

The virtual political identities can bring to the scene this type of reversibility with consequences. It is true that in the multiplicity characteristic to the virtual identity there would not be a single form of conciliation between the online world and the offline world, but between them their potential character for critical and creative experimentation is singular. I want to say that the reversible character of the medium can at times be cathartic, at times ludic, subversive, trangressive, emancipative, dconstructive, frustrating, indifferent... In fact, the reversibility is the appearance, it is never clear that the background is completely reversible.

One example would be the sexuality objectified in chats, where the very enunciation of the conversation becomes the performative constituting the being, even if the being is incredibly ephemeral. The agility of the interpersonal identity construction in chats makes us think that they have generated a potential context for the deconstruction of sex and sexuality. Nevertheless, some ethnographic works on the topic, such as that of Rival, Slater and Miller, advise precisely of the contrary, of a "form of experimenting pleasures in quite stable constructions" (Rival, Slater y Miller, 2003:34), that is to say of forms of sexuality that have as a goal "finding a way back to everyday versions of sexuality and family." Thus, even if in a chat we are aware of the performative nature of our identities and of constituting the other by authenticating it, an interplay is produced between the performativity of both and the desire (be what you want as long you accept your requests)" so that the deconstructive possibility becomes confined by the limitation of the game, the deception and the fugacity; as if we thought "nothing of what I do will transcend"; as if in our relations, through chats we limit ourselves to the sublimation of our desires to "reinforce" later (in the return to the materiality of the off-line life) what we are socially; like a self-regulatory mechanism made possible by the mask and the virtual anonymity and also, by the 
intersubjective context which generates cyberspace. This use of identity cannot be underestimated.

In this line, it should be suspected that the forms in which the Internet has been territorialized in the past decade increasingly condition the identity and subjective interplay. Today, it is the social networks that operate as limiting interfaces of the presentation of the subject and of many of its intersubjective relations. It appears that it is the biopolitics of these networks, in their primacy of profiles of facialness, and in the rapid and conservative breakdown of categories of identity managed and incentivized by data bases regulated by companies and capital, which now want to violently instrumentalize online identities.

The affectation of the social network on the mark of contemporary conviviality does not go unnoticed. A mark characterized by the demand of an "I" sustained in images of reality. I want to say, an "I" accredited by photography, video and confirmation of the "other" in relation to its existence and life; an "I" published and controlled that each day donates fragments of its life to the networks, thinking (naively) that it "uses" them, when in essence, it is they (the networks) that use and take advantage of this "I." And they do so, especially, from an identity prism, placing value not on what we do, but on what links we have with the other, with those with whom we form a type of fast and diverse collectivities. Collectivities, which because of their general nature (and by their quantity) cohere only slightly.

It would thus appear that the networks contribute to establish a competitive social mark, characterized by the need for a positioning of the real I among the tangle of digital I's that want to be made visible online. And that this would describe, at least partially, this struggle to be seen as a way of existing on the Internet, as a drive that we confront daily as connected subjects.

We should, however, observe in this recent mark that tells us about identity on the social networks, as its biopolitics have stimulated changing but slight ties, derived from sharing passions, age, friendship, projects or temporal interest. Ties that in any case have served a neoliberal system that knew how to profit from 
them, reinforcing (secondarily) identities distanced from old and fundamentalist dogmas, capable of defining themselves each time in various ways to gradually change. And, curiously, here is perceived a power of resistance that should not be underestimated. We should not forget that for a long time the subjects have rebelled against strong ties like those that easily led us to conflict, to wars and to dogmatisms.

Strong identities have not characterized either the recent epoch or these forms of liquid union on the networks (above all social networks); at least not in the sense of that commonly authorized by sharing ties specific to an ideological, political or moral commitment. Nevertheless, the network and its dilligences show us an image of high sociability, of the possibility for nearly infinite and immediate connection with others. From the nearly instantaneous and rapid step of the I to potential "multiple communities," without the needed reflexive mediation, post, tweet, mass invitations or mailings. But let's not overlook how this availability depletes its power upon eclipsing with quantity and context the lack of depth of a form of connection that is tenuous because it is excessive; a rapid tie that does not need more commitment than to be tuned in and touch of the hand (send) from one's own connected room or from any of the various connections that public-private space online allow us today, where we can see and do without necessarily mediating a counterpart or that this counterpart demand too much of us.

This possibility for a rapid connection appears to dilute the ability for attention by distractions from a plethora of stimuli. A connection that is increasingly premeditated by marketingtechniques and capitalist dynamics of "affective management" ${ }^{4}$ on

4 The term afectividad [affection] in relation to capitalism and affective work is not used here in the sense given to it by studies of the affective economy from economic anthropology and gender studies, but what is developed in this text of references from Lazzarato (1996), Knowbotic Research en Io_Lavoro Inmateriale (http://aleph-arts.org/io lavoro/), and especially by Michael Hardt in his essays about Affective Labor (1999), and later works developed by Juan Martín Prada in 
the Internet. It should be remembered that a large part of the services that characterize these dynamics are supported by the management and commercialization of time (time for us to relate and consume "the others" to connect and use while we produce and return...). These services are oriented to guarantee the permanence of those who use them, amplifying the number of ties, the number of minutes dedicated to our ties, and therefore, the number of minutes of using the space that welcomes us and that demand from us a desire: "to return."

The "I" is seduced by having it participate in the space that it generates with its own vital experience, committing it in a space that symbolically identifies it, which it considers its own, and "how can one not return to the digital home, to the place where everyone knows your name," where a voice (that we imagine to be feminine) appears to say: "Welcome to your social network. Here we require - gently - more from you interlacing you with other people who you certainly know, or that know those who you know; people who know your name, what you do and what you like" (and [this voice] will insist), "people who know your name." It cannot be taken lightly, this constant interaction that is stimulated on the networks in exchange for friendly ties with other people, converting a trend into a community "need" of the time: "to be" in the world constructing and inhabiting your social networks. To have thousands of contacts and friends (because there could be no better commercial brand than affection) and in parallel and significantly "to be possessed by your network."

But then, what do we need for the critical liminality that I mentioned earlier? This territory where one can reflexively explore what was repressed or silenced in cyberspace. From my perspective, this question could have various possible replies but that which most interests me would need to reconsider "the reversibility with consequences", that I mentioned earlier, that is, a reflective affectation of our experimentations on the Internet. This

"Vinculo-a" and in his essays about the Internet and economies of affection (2006 y 2012). 
is to a large degree the focus of the work of many artists of parody who place themselves and put us in the place of the "other," not as mere empathy but as something deeper that leads us to "be" the other. We raise an example, a possible and fictitious conversation, let's say in a virtual room. We hear or read the following:

- hello, are you a man or a woman?

- hello. I'm a man, heterosexual, white, with brown hair, handsome, 45 years old, educated, I'm a good guy. I'm looking for friendship and whatever happens.

-OK. Good luck. I'm a heterosexual man, I'm looking for a girl. Good-bye.

-Don't go. I'm also a girl.

-Ok. Let's start again.

Of course what is disturbing about cyberspace is that in it converge different forms of identity reception and production and that in this diversity, different from other media such as television, reflection would be viable. However, we can intervene on our own time and on our conscious, to go beyond the simple role of resigned viewers, accepting and conformed bodies. In fact, Derrida suggests when facing the power of capital an insubordination of the computer screens through the network (Derrida and Siegler, 1998). That is to say, he reveals a difference and a political potential of the computer connected in relation to others like the television screen. This, television screen, Bourdieu insisted, does not favor thinking because it annuls the time to think (Bourdieu, 1997). And here we find another key element in our approximation to the identity experimentation on the Internet: the time of reflection, which is so scarce today. In this sense, the comparison with television continues to be illustrative. The celerity of television is favored by the symbolic effect of the only images that tolerate it, those that reinforce ideas that were already within ourselves, which "take for granted" that what they communicate does not have to be questioned. Those that allude not to a knowledge, or to a present and active memory (more particular to reading and to 
some forms of navigation on the Internet), but to emotions, identifications and projections, that is to say, the past; and in the case that concerns us, to the repetition of identity models. This tie with the already lived incites the exchange of "preconceived ideas" and clichés, the only ones that tolerate it, because they were already in us: the topics, the thoughts that conform the stereotyped and symbolic identities. Of course the physical limit of the screen connected to the Internet is not as evident today as the limit that we noticed eaerlier in television. I want to say that the screen can be duplicated or multiplied not only physically but functionally in a single surface, so that nearly everything converges - potentially on the connected screen. This possibility warns of the risk of succumbing to the loss of the distance needed for a minimal reflective attitude that allows becoming aware of what we are and about what we can be in our lives, including virtual ones; a time for thinking that is capable of giving our practice political meaning.

In any case, what we indicate here is the need to give value to the circumstances (both their potential and limits) of identity production and reception through the screen, questioning what we are, not as something completed and definitive, but as an uncompleted process and upon which we can intervene individually and collectively, but emphasizing the importance that the devices themselves through which we express ourselves and relate with each other have to stimulate or annul this possibility for intervention.

In these Internet years many of us have thought that its singularities as a horizontal and interfaced medium have allowed politically more transgressive identity action to demand, resignify and or overcome the symbolic burdens of the bodies. To observe today the medium and its analyses we discover that facing the more emancipating and creative possibility, the tendency led by the "industries of the I" moved by capital, come given by the accreditation of the I through images of reality and a context that demands more of us more rapidly, establishing, as much as possible, stereotyped and conservative identities. Of course the transgressive possibility does not imply the determination to 
exercise it, but the deconstructive potential of the network continues to exist and demands to be practiced by those who demand awareness and imagination about the neutralizing trends that convert us into an uncritical mass that "repeats world."

It continues to be necessary to critically and politically reflect on the online identity and subjective construction and on the body "after the Internet," identifying the new forms of symbolic oppression online (current ones and those to come) hidden with new technological disguises. To problematize about its burdens and possibilities helps us to be active agents of our individual and collective changes in a network society and also, to live "alongside ourselves" (Butler, 2006:36), not only with mourning and passion, as Butler suggests, but with risk and creativity.

\section{Bibliography}

BARTHES, Roland. El sistema de la moda y otros escritos. Barcelona, Paidós, 2003. 2010.

BenjAmin, Walter. Historias y relatos. Barcelona, Península, 1997.

BEY, Laura. La vida en mi primera IP. Obra artística, 2010 [http://www.2red.net/mividaenlaprimeraip].

BorGES, Jorge Luis. Ficciones. Madrid, Alianza Editorial, 1971.

BOURDIEU, Pierre. Sobre la televisión. Barcelona, Anagrama, 1997.

BRAIDOTTI, Rosi. Metamorfosis: hacia una teoría materialista del devenir. Madrid, Akal, 2005.

BUTLER, Judith. Bodies that Matter: On the Discursive Limits of "Sex". Londres, Routledge, 1994. . Deshacer el género. Barcelona, Paidós, 2006.

CsORDAS, Thomas. Embodiment and experience. The existential ground of culture and self. Cambridge, Cambridge University Press, 1994. 
Deleuze, Gilles y GuATtARI, Felix. Mil mesetas. Capitalismo y esquizofrenia. Valencia, Pre-textos, 1994.

DERRIDA, Jacques. La deconstrucción en las fronteras de la filosofía. Barcelona, Paidós, 1989.

y STIEGLER, Bernard. Ecografías de la televisión. Buenos Aires, Eudeba, 1998.

FouCAult, Michel. Microfísica del Poder. Madrid, La Piqueta, 1980.

. Materiales de sociología crítica. Madrid, La Piqueta, 1986.

. Hermenéutica del sujeto. Madrid, La Piqueta, 1994.

GARCía CANCLINI, Néstor. Definiciones en transición. En MATO, D. Estudios latinoamericanos sobre cultura y transformaciones sociales en tiempos de globalización. Buenos Aires, Clacso, 2001, pp.57-68.

- Google es más poderoso que las cadenas de tv o las discográficas. Revista de Cultura N. Tecnología y Comunicación, 2011 [http://www.revistaenie.clarin.com].

GIDDENS, Anthony. Modernidad e identidad del yo: El yo y la sociedad en la época contemporánea. Península, Madrid, 2000.

HARDT, Michael. Affective Labor. Boundary 2, vol. 26, $n^{\circ} 2$, Verano 1999, pp.89-100.

JONES, Amelia. (ed.) The Feminism and Visual Culture Reader. Londres, Routledge, 2003.

LAZZARATO, Maurizio. Knowbotic Research en Io_Lavoro Inmateriale. 1996 [http://aleph-arts.org/io_lavoro].

LÉVINAS, Emmanuel. Totalidad e infinito. Ensayo sobre la exterioridad. Salamanca, Sígueme, 2012.

MARTín PRADA, Juan. Economies of Affectivity. Multitudes, 2006 [http://www.multitudes.net/Economies-of-affectivity].

. Prácticas artísticas e Internet en la época de las redes sociales. Madrid, Akal, 2012.

Rival, L., Slater, D. y Miller, D. Sexo y socialidad Etnografías comparativas de objetivación sexual. En: NIETO, José Antonio. Antropología de la sexualidad. Madrid, Talasa, 2003, pp.27-54. 
TURKLE, Sherry. Life on the Screen. Identity in the Age of the Internet. Nueva York, Simon and Schuster, 1985.

TURNER, Victor. La selva de los símbolos. Madrid, Siglo XXI, 1980.

TURNER, Víctor y TURNER, Edith. Image and Pilgrimage in Christian Culture. Nueva York, Columbia University Press, 1978.

Velasco, Honorio. Cuerpo y Espacio: Símbolos, Metáforas, Representación y Expresividad de las Culturas. Madrid, Ramón Areces, 2007.

ZAFRA, Remedios. Netianas. N(h)acer mujer en Internet. Madrid, Lengua de trapo, 2005. . Un cuarto propio conectado. Madrid, Fórcola, 2010.

. (coord.) X0y1. Ensayos sobre género y ciberespacio. Madrid, Briseño, 2010.

. (h)adas. Mujeres que crean, programan, prosumen, teclean. Madrid, Páginas de Espuma, 2013. . Ojos y capital. Bilbao, Consonni, 2015.

ŽıZÊK, Slavoj. Lacrimae Rerum. Ensayos sobre cine moderno y ciberespacio. Madrid, Debate, 2006. 